\title{
The Combined Effects of Financial Derivatives and Discretionary Accruals on the Value Relevance of Earnings and the Book Value of Equity
}

\author{
EttyMurwaningsari, ${ }^{*}{ }^{*}$ Sidharta Utama, ${ }^{b}$ and Hilda Rossieta ${ }^{b}$ \\ ${ }^{a}$ Faculty of Economics, Universitas Trisakti, Indonesia \\ ${ }^{\mathrm{b}}$ Faculty of Economics, University of Indonesia, Indonesia
}

\begin{abstract}
This study aimed to understand (1) the association between the use of discretionary accruals and financial derivatives, taking into consideration the implementation of revised PSAK 55 (1999), which was adopted from SFAS 133; (2) the combined effects of derivatives and discretionary accruals on the value relevance of earnings and equity. The analysis used panel data regressions and the Wald test over the period from 2001-2008. The results showed a positive or complementary association between derivatives and discretionary accruals. The positive association implied that managers tended to intensify the use of discretionary accruals to offset a higher use of derivatives. Price and return models demonstrated negative significant effects of derivatives on the value relevance of earnings. The return model showed negative significant effects of discretionary accruals on the value relevance of earnings but negative effects on the value relevance of equity with the price model.
\end{abstract}

\begin{abstract}
Abstrak: Tujuan penelitian untuk mengetahui (1) hubungan penggunaan derivatif keuangan setelah implementasi PSAK 55 (1999) yang diadopsi dari SFAS 133 terhadap penggunaan discretionary accruals; (2) pengaruh derivatif dan discretionary accrual terhadap relevansi nilai dari laba dan ekuitas. Analisis menggunakan regresi panel data dan uji Wald, periode tahun 2001-2008. Hasil penelitian menunjukkan derivatif dan discretionary accrual memiliki hubungan positif atau komplementer. Pengaruh derivatif terhadap relevansi nilai laba menggunakan model harga dan return menunjukkan arah negatif, namun tidak ada pengaruh terhadap relevansi nilai ekuitas. Pengaruh discretionary accruals terhadap relevansi nilai laba menggunakan model return menunjukkan arah negatip dan model harga menunjukkan arah negatif terhadap relevansi nilai ekuitas.
\end{abstract}

Keywords: discretionary accruals; financial derivatives; the value relevance of earnings; the value relevance of equity

JEL classification: G10, G30

* Corresponding author's e-mail: etty_nasser@yahoo.com 


\section{Introduction}

This study extends Barton (2001). His study was conducted during 1994-1996 - a period before the implementation of the Statement of Financial Accounting Standards (SFAS 133) on Accounting for Derivative Instruments and Hedging Activities. Barton (2001) showed a negative and substitutive relationship between financial derivatives and discretionary accruals. This implied that managers decreased the use of discretionary accruals to offset the higher use of derivatives, which suggested the adoption of hedging activities by firms. Barton's study (2001) was further verified in a study conducted in Indonesia using data from 2001-2008 -a period when SFAS 133 was active, having been adopted by the Indonesian Statement of Financial Accounting Standards (PSAK 55/ 1999) - with different findings from that found by Barton (2001). In this case, the association between financial derivatives and discretionary accruals was positive or complementary, which suggested a higher use of discretionary accruals by managers to offset the effects of the higher use of derivatives and showed that firms were engaged in speculative activities and hedging that was noncompliant with PSAK 55 (1999).

According to Bank Indonesia's Indonesian Banking Accounting Guideline/PAPI (2008: 229), financial derivatives are used for the following purposes: (1) trading/speculative activities. Derivatives transactions for trading purposes fall into the category of fair value through profit and loss: (2) hedging against certain risks, which is defined as follows: (a) if derivatives transactions that are specifically used to manage the risks of the relationship between derivatives instruments and hedged items meet certain criteria, then hedging accounting can be implemented: (b) if derivatives transactions that are used for hedging do not meet the hedging accounting criteria required by the PSAK, then the derivatives transactions are treated in a similar fashion to those for trading purposes.

Meanwhile, financial statements revealed that 150 firms disclosed derivative transactions that were noncompliant with PSAK 55 (1999). This is assumed to be speculative activities by this research. Such disclosures were driven by several reasons, including efforts by Indonesian firms to adjust to the newly adopted PSAK 55 (1999). In particular, PSAK 55 (1999) requires that hedging accounting be implemented only if (i) there is documentation for the relationship between hedging and a firm's risk management objectives; (ii) a hedging implementation strategy is readily available; and (iii) an assessment of effective hedging is routinely conducted. The assesment of hedging activities is effective at the beginning and during the contract period. However, paragraph 30 in the standards (PSAK 55:30,1999) defines the assessment for effective hedging activities too broadly, with a lack of focus on how to determine the score range for an effective hedging, which may result in different interpretations in its implementation across firms. Fortunately, such an issue was addressed in the revised PSAK 55 (2006) Application Guidelines 125. The statement is as follows: "when the assesment results in a score range of between 80 percent to 100 percent, a financial derivative is considered compliant with the regulation.'Thus, it is an effective hedging, and the accounting treatment of unrealized gains/ losses is reported in equity. As firms disclosed their hedging that was noncompliant with PSAK 55 (1999), the accounting treatment of unrealized gains/losses was reported in the current year's income statement, thus treating it as a speculative activity. This gave rise 
to earnings volatility that was higher than hedging activities (Aabo 2007). The market, which prefers low earnings volatility, pays little attention to stock prices (Graham et al. 2005), and this leads to earnings management by managers.

The above situation was worsened by the use of speculative activities in subprime mortgage schemes in the United States in mid2007 which eventually led the nation to a financial crisis. Indonesia faced a similar situation. An analysis of the notes to the financial statements of public firms during the sample period shows that 54.2 percent of firms reported losses from financial derivatives. This would increase the probability of financial distress and debt contract violations (Asquith et al. 2005). Hence, the use of speculative actions, characterized by high earning volatility will hinder the value relevance of earnings.

Beaver (1998) suggested that accounting numbers were value-relevant when they were associated with the market value of equity. Therefore, accounting information was value-relevant if the stock price movement was associated with the disclosed information. Prior research suggested that accounting information played a role in determining the equity values of both an income statement and a balance sheet (Collins and Kothari 1989 ). Accounting information associated with earnings management can be gathered through artificial smoothing, such as abnormal accruals, or through real smoothing, such as financial derivatives (Barton 2001; Moffit 2001; Pincus and Rajgopal 2002). This study, therefore, aimed to extend the use of derivatives and discretionary accruals as variables that increase or decrease the value relevance of earnings and equity. As we were aware, no available literature on the value relevance of earnings and equity book value discussed the difference between the effects of financial derivatives and discretionary accruals on the value relevance of earnings and equity book value. Prior research, such as Huang et al. (2008), only discussed the effects of financial derivatives and discretionary accruals on the market value. In Huang et al. (2008), for instance, they maintained that the market value decreased in proportion to the use of abnormal accruals and increased in proportion to the use of derivatives.

Our study aimed to shed light on: (1) the relationship between financial derivatives and discretionary accruals (2) the combined effects of the use of derivatives and discretionary accruals on the value relevance of earnings and equity; and (3) the contrasting effects between derivatives and discretionary accruals on the value relevance of earnings and equity. In addition, this study expects to contribute to the growing knowledge on the relationship between discretionary accruals and speculative activities. Such a relationship is now found to be complementary, meaning it is capable of decreasing the value relevance of earnings. Since it is the first study that explores the subject matter in Indonesia, it is considered important. Its role as a source of reference is even more prominent with the implementation of PSAK 55 (1999) -adopted from SFAS 133- which many firms are still struggling to comply with, particularly in terms of reporting their hedging activities. This research also contributes to a better understanding of the complementary relationship between derivatives and discretionary accruals that was an extended test to the value relevance of earnings and the book value of equity, which builds on prior studies on the value relevance of discretionary accruals (Whelan and McNamara 2004; and Wiedman and Marquardt 2004). 
Literature Review and Hypothesis Development

\section{The Relationship between \\ Financial Derivatives and Discretionary Accruals}

Barton (2001) noted that earnings were the sum of cash flows. This suggests that an earnings variance is the function of cash flows and accrual variances, with the relationship between cash flows and accruals being as Equation 1.

$$
\begin{aligned}
& \text { Earnings variance }\left(\sigma_{L}^{2}\right)= \\
& \text { Cash flow variance }\left(\sigma_{K}\right)+\text { Accrual variance }\left(\sigma_{A}\right) \\
& +2 \text { accrual covariances, cash flow }\left(2 \rho_{K A} \sigma_{K} \sigma_{A}\right)
\end{aligned}
$$

Managers can therefore manage earnings volatility by adjusting cash flows and accrual volatility. Barton (2001) suggested that the relationship between financial derivatives and discretionary accruals was likely to be substitutional or complementary. The first argument suggested that derivatives with hedging would decrease the volatility of earnings. Thus, the discretionary accruals could be substituted by the use of hedging. In this sense, an increase in the use of financial derivatives will decrease discretionary accruals. Meanwhile, the second argument suggested that financial derivatives with speculative actions would increase the volatility of earnings. Thus, the discretionary accruals were still needed for income smoothing. Discretionary accrual cannot be replaced by financial derivatives, because they complement each other. In this sense, an increase in the use of financial derivatives will be followed by an increase in the discretionary accrual.
Findings by Barton (2001), which used the pre-SFAS-113 1994-1996 data, showed that a substitution relationship existed between financial derivatives and discretionary accruals. The findings find support in Moffitt (2001) and Pincus and Rajgopal (2002). In the later part of his study, Barton (2001) predicted that the implementation of SFAS 133, which was adopted as PSAK 55(1999) in Indonesia, would lead to a more transparent use of derivatives; hence, it would increase costs of reporting. The cost-inefficient criteria includes skillful human resources, up-to-date technologies, and completeness of documents (e.g. assessment of the effectiveness of hedging). This stems from the fact that the criteria of financial derivatives reporting for hedging purposes could not be met. Therefore, 150 firms disclosed their hedgings that were noncompliant with PSAK 55 (1999), where unrealized gains/losses were reported in the current year's income statements, as if they were speculative activities. This gave rise to earnings volatility that was higher than hedging activities (Aabo 2007). Managers step up the use of discretionary accruals to limit an increase in earnings volatility on account of a higher use of speculatives. Based on the argument above, the proposed hypothesis is as follows:

\section{Hypothesis $1\left(H_{1}\right)$ : the use of derivatives is posi- tively associated with discretion- ary accruals.}

\section{The Effects of the Use of Financial} Derivatives on the Value Relevance of Earnings and the Book Value of Equity

The value relevance was developed from the first hypothesis -the complementary relationship or the positive associations- stemming from a higher use of speculatives followed by an increase in discretionary accru- 
als. The use of financial derivatives entails market risks, such as exchange rate and interest rate risks. Market risks, also known as systematic risks or stock's beta, are nondiversifiable risks (Djohanputro 2008). Systematic risks are negatively associated with the Earnings Response Coefficient, which is the relationship between stock prices and earnings. This suggests that the higher (lower) the risks of an entity the lower (higher) the value relevance of earnings (Collins and Kothari 1989; Kothari and Zimmerman 1995). The use of speculatives, hence, decreases the value relevance of earnings.

Meanwhile, highly risky earnings volatility is likely to give rise to financial distress or violation of debt contracts (Asquith et al. 2005). Barth et al. (1998) noted that a financially less healthy entity or an entity with high volatility gave more importance to cash flows and lower importance to income statements. For that reason, the use of speculatives that give rise to market risks and financial distress decreases the value relevance of earnings and increases the value relevance of equity, as investors transfer to equity (Collins and Kothari 1989; Barth et al. 1998). Accordingly, the proposed hypotheses are as follows: Hypothesis $2.1\left(H_{2.1}\right)$ : the use of derivatives is negatively associated with value relevance of earnings

Hypothesis $2.2\left(\mathrm{H}_{2.2}\right)$ : the use of derivatives is positively associated with value relevance of equity.

\section{The Effects of Discretionary Accruals on the Value Relevance of Earnings and the Book Value of Equity}

Prior studies by Whelan and McNamara (2004) as well as Wiedman and Marquardt (2004) argued that earnings management, as reflected by high discretionary accruals served as an indicator of low earnings reliability (Richardson et al. 2004). Less reliable earnings would drive the market to reduce its reliance on earnings in determining a firm's value and turn to equity (Burgstahler and Dichev 1997). Consequently, when an entity is engaged in discretionary accruals, the market is expected to reduce its reliance on earnings information in determining a firm's value, while giving more importance to the book value of equity in communicating stock prices. In contrast, Subramanyam (1996) noted that earnings management was driven by a motivation to efficiently communicate private information about future economic potentials which cannot be accommodated by applicable accounting standards.

Hence, when discretionary accruals are perceived as a credible signal, earnings reliability will increase (Subramanyam 1996), which in turn will strengthen the value relevance of earnings. On the other hand, less reliable earnings will occur from the use of opportunistic discretionary accruals, which then will reduce the value relevance of earnings (Whelan and McNamara 2004). Furthermore, when the reliability of earnings (equity book value) is low, the reliability of equity book value (earnings) is high (Burgstahler and Dichev 1997). Accordingly, discretionary accruals or derivatives have positive or negative effects on the value relevance of earnings and equity. The proposed hypotheses, thus, are as follows:

Hypothesis $3.1\left(H_{3,1}\right)$ : discretionary accruals are associated with the value relevance of earnings.

Hypothesis $3.2\left(H_{3,2}\right)$ : discretionary accruals are associated with the value relevance of equity book value. 
The Contrasting Relationship between Financial Derivatives and Discretionary Accruals with the Value Relevance of Earnings and Equity Book Value

Since earnings consist of components of accruals and cash flows, one needs both components to be able to conduct earnings management. Although both cash flows and accruals will end up as earnings, their effects on the quality of earnings are different. The quality of earnings increases when cash flows increase or accruals decrease (Sloan 1996). Furthermore, Lev and Zarowin (1999) stated that information in accrued earnings had a lower quality compared to information in cash flows. The reason is that accrued earnings give more discretion opportunities to the management, indicating low accuracy, validity, and reliability. Consequently, markets will react more strongly to information on earnings that comes from cash flows rather than from accruals. On the other hand, information on cash flows is considered as real earnings management, which also includes the use of derivatives. If the use of derivatives leads to an unrealized gain or loss, firms will then recognize them in the equity account. Hence, financial derivatives should have a stronger (weaker) effect than the discretionary accruals on the value relevance of equity (earnings). This argument is based on Whelan and McNamara (2004) as well as Wiedman and Marquardt (2004). They showed that when the reliability of earnings (equity book value) was low, then the reliability of equity book value (earnings) was high. The proposed hypotheses, thus, are as follows:

Hypothesis $4.1\left(H_{4.1}\right)$ : the use of financial derivatives has weaker effects on the value relevance of earnings compared to the use of discretionary accruals
Hypothesis $4.2\left(H_{4.2}\right)$ : the use of financial derivatives has stronger effects on the value relevance of equity compared to the use of discretionary accruals.

\section{Methods}

\section{Sample Selection}

The research population was all firms that conducted financial derivatives transactions and listed their stocks on the Indonesian Stock Exchange over the period of 20012008, which produced 350 observations. However, 20 observations from the 20012008 financial statements were not available and therefore were excluded, thus reducing the number to 330. This figure was further reduced to 199 as 131 derivative users had not been actively engaged in derivative transactions. The sample excluded 78 banks and non financial institutions due to differences in the accounting practices of specific industries and the use of financial derivatives as stipulated in a special regulation. Moreover, the model used to measure the amount of discretionary accruals in the financial industry differs from that used in other industries.

\section{Variables and Measurement}

Stock Prices $(\mathrm{P})$ were measured by the closing prices at the end of the publishing month, which was March, three months subsequent to the balance date of December 31 . This approach was used to ensure that stock prices fully reflected the information contained in the annual reports. Meanwhile, Discretionary Accruals (DAC) were measured using the Kothari et al. (2005) model. The model was chosen because it took into account the Return-on-Assets that controls for 
the effects of firms' performance on accruals. The measurement is as Equation 2.

\section{Total Accrual}

$$
\begin{aligned}
T A C_{i t}= & N i_{i t}-C F O_{i t} \\
D A C_{i t}= & T A C_{i t} / T A_{i t-1}-\left\{\alpha_{1}\left[1 / T A_{i t-1}\right]+\right. \\
& \alpha_{2}\left[\Delta R E V_{i t} / T A_{i t-1}-\Delta R E C_{i t} / T A_{i t 1}\right] \\
& +\alpha_{3}\left[P P E_{i t} / T A_{i t-1}\right]+\alpha_{3} R O A_{t}
\end{aligned}
$$

where, $\mathrm{TAC}_{\mathrm{it}}=$ total accruals of firm $i$ in year $t ; \mathrm{CFO}=$ Cash flow from operation; $\mathrm{DAC}_{\mathrm{it}}=$ Discretionary accruals of firm $i$ in year $t, \mathrm{TA}_{\mathrm{it}-1}=$ Total assets of firm $\mathrm{i}$ in year $t$, $\Delta \mathrm{REV}_{\mathrm{it}}=$ Change of net sales of firm $i$ in year $t, \Delta \mathrm{REC}_{\mathrm{it}}=$ Change of net receivables of firm $i$ in year $t, \mathrm{PPE}_{\mathrm{it}}=$ Property, plant, equipment of firm $i$ in year $t, \mathrm{Ni}_{\mathrm{it}}=\mathrm{Net}$ income of firm $i$ in year $t, \mathrm{ROA}_{\mathrm{t}}=$ Return on Asset in year $t$ (Net income divided by $\mathrm{TA}_{\mathrm{t}}$ )

Earnings per Share (EPS) were measured using earnings before extraordinary items deflated by outstanding shares (Whelan and McNamara 2004). Furthermore, the Book Value of Equity per share (EBV) was measured by the total equity divided by the outstanding shares (Whelan and McNamara 2004), while Derivatives (DERIV) were measured by the notional amount of foreign exchange derivatives scaled by lagged total assets (Barton 2001; Moffitt 2001; Pincus and Rajgopal 2002). A notional amount is an amount in a unit of currency, shares and/or other units stipulated in an agreement (PSAK 55/1999). In this study, Information Asymmetry (IA) was proxied by a bid-ask spread using an eleven-day event window -five days before $(-5)$ and five days after $(5+)$ an accounting earnings reporting date (Brown and Warner 1985). A long event window was not preferable because of concern over its potential accumulated effects on earnings. Lee
(1993) suggested that the combination of a bid-ask spread and market depth data could signal potential information asymmetry prior to an earnings announcement. Therefore, the information asymmetry of firm $i$ at day $t$ was proxied by ADJSPREAD ${ }_{\mathrm{i}, \mathrm{t}}$ or Residual Spread $\left(\varepsilon_{i, t}\right)$, with the Equation 3:

$$
\begin{aligned}
\operatorname{SPRE} A D_{i, t}= & {\left[\left(\text { ask }_{i, t}-\text { bid }_{i, j}\right) /\right.} \\
& \left.\left\{\left(\text { ask }_{i, t}+\text { bid }_{i, t}\right) / 2\right\}\right] \times 100 \%
\end{aligned}
$$

where, $\mathrm{SPREAD}_{\mathrm{i}, \mathrm{t}}=$ spread between ask and bid divided by the amount of ask and bid divided by two; $\mathrm{ASK}_{\mathrm{i}, \mathrm{t}}=$ highest ask price of the shares of firm $i$ on day $t, \mathrm{BID}_{\mathrm{i}, \mathrm{t}}=$ lowest bid price of the shares of firm $i$ on day $t$.

$$
\begin{aligned}
\operatorname{SPREAD}_{i, t}= & \alpha_{0}+\alpha_{1} \operatorname{PRICE}_{i, t}+\alpha_{2} \operatorname{VAR}_{i, t} \\
& +\alpha_{3} \operatorname{TRANS}_{i, t}+\alpha_{4} \operatorname{DEPTH}_{i, t} \\
& +\operatorname{ADJSPRE} A D_{i, t}\left(\varepsilon_{i, t}\right)
\end{aligned}
$$

where, PRICE $\mathrm{i}_{\mathrm{i}, \mathrm{t}}=$ closing price of firm $i$, day $t$ in event window; $\operatorname{VAR}_{\mathrm{i}, \mathrm{t}}=$ variant of a daily return level over the observation period of firm i's shares on day $t$; TRANS $S_{i, t}=$ amount of share transactions of firm $i$, on day $t$ in each event window; $D_{E P T H}=$ an average amount of shares of firm $i$ on all quotes (an available amount during "ask" added by that during "bid" divided by two) in every day t in event windows; $\operatorname{ADJSPREAD}_{\mathrm{i}, \mathrm{t}}\left(\varepsilon_{\mathrm{i}, \mathrm{t}}\right)=\mathrm{re}$ sidual errors used as the adjusted measure of SPREAD and used as the proxy of information asymmetry for firm $i$ day $t$.

$\mathrm{DAC}_{\mathrm{t}-1}$ is the absolute value of DAC in the prior-year period (Barton 2001). Dividend Payout Ratio (DPR) was measured by the cash dividend to pre-managed earnings ratio (earnings before extraordinary items substracted by discretionary accruals) divided by lagged total assets (Barton 2001). Control 
variables were as follow, (1) capital structure (CS) was measured by the total debt to total asset ratio (Watts and Zimmerman 1986); (2) growth opportunity (GO) was measured by the ratio of market capitalization (closing price multiplied by outstanding shares) to book value of equity (Collins and Kothari 1989); (3) quality of auditor (QA) proxy employed the measurement of a public accountant office, which used a dummy, $1=$ big four, and $0=$ non-big four; (4) firm size (SIZE) was measured by the natural logarithm of total assets.

\section{Selection Models}

Gujarati (2003) stated that the use of Ordinary Least Squares (OLS) would result in an inconsistent and biased estimation in an estimation model that had several equations interdependent with each other. According to Greene (2003), the steps to determine the suitable model were as follows: (1) to test between pooled OLS and a fixed effect model, one should test the correlation between the cross-section specific effect and the dependent variable using the F-test and the Chi-Square test. If a correlation existed, then pooled OLS was inconsistent, hence use the fixed effect model; (2) to test between the fixed effect and random effect models, one could use the Hausmann specification test, which tests the correlation between unobserved individual random effects and a dependent variable. If the null hypothesis was rejected, then the random effect model was inconsistent, hence use the fixed effect model.

\section{Research Models}

\section{Model for $H_{1}$}

The relationship between financial derivatives and discretionary accruals is shown by the Equation 5 .

$$
\begin{aligned}
\mathrm{DAC}_{\mathrm{it}}= & \alpha_{0}+\alpha_{1} \mathrm{DERIV}_{\mathrm{it}}+\alpha_{2} \mathrm{CS}_{\mathrm{it}}+\alpha_{3} \mathrm{GO}_{\mathrm{it}} \\
& +\alpha_{4} \mathrm{IA}_{\mathrm{it}}+\alpha_{5} \mathrm{DAC}_{\mathrm{it}-1}+\alpha_{6} \mathrm{DPR}_{\mathrm{it}}+ \\
& \alpha_{7} \mathrm{QA}_{\mathrm{it}}+\alpha_{8} \mathrm{DERIV}^{*} \\
& \text { Dspeculation }+\alpha_{9} \mathrm{D}_{\text {speculation }+} \\
& \varepsilon_{\mathrm{it}}
\end{aligned}
$$

The first sensitivity test, was conducted by comparing the effects of financial derivatives on discretionary accruals using the dividend payout ratio measured without negative premanaged earnings. The dividend payout ratio with negative pre-managed earnings showed that there were more discretionary accruals than cash flows in the firms' earnings. This is consistent with Sun and Rath (2010) who found that managers used earnings management to boost earnings when premanaged earnings were below zero. The second sensitivity test, namely a classification test, was conducted to support the hypothesis test. According to the notes in the financial statements, derivatives could be categorized based on the derivatives motive as follows: (a) nine derivatives were reported as speculative; (b) 150 derivatives were reported as hedging, which were noncompliant with PSAK 55 (1999); (c) 40 derivatives were reported as hedging transactions, that were compliant with PSAK 55 (1999). Hence, the test used a dummy variable as follows: Dspeculation= 1 , if the disclosure of the notes to the financial statements were speculative and hedging that was noncompliant with PSAK 55 (1999); 0, if the disclosure of the notes to the financial statements was hedging.

\section{Model for $\mathrm{H}_{2}$ and $\mathrm{H}_{3}$}

The effects of financial derivatives on the value relevance of earnings and equity using the pooled regression (Whelan and McNamara 2004). Interaction coefficients 
showed the strengthening and weakening effects of financial derivatives and discretionary accruals on the value relevance of earnings and equity. The first sensitivity test using a cumulative abnormal return was conducted on the assumption that a price model may raise econometric concerns, even though the estimated slope coefficients of the price model is less biased than that of the return model. Moreover, Easton et al. (1998), who carried out a similar observation, suggested that a return specification be adopted. Abnormal return is estimated using a 12-month event window from April in year $\mathrm{t}$ to March in year $t+1$ (Ali and Zarowin 1992). The second sensitivity test aimed to see whether the firms in the sample took certain corporate actions such as stock splits or dividend payments, which logically could influence the magnitude and movement of stock prices. Hence, the variables were deflated by the number of outstanding shares, as suggested by prior studies, such as Easton et al. (1998). The model is as Equation 6 and Equation 7.

$$
\begin{aligned}
P_{i t}= & \gamma_{0}+\gamma_{t} E P S_{i t}+\gamma_{2} E B V_{i t}+\gamma_{3} D E R I V_{i t}+ \\
& \gamma_{4} E P S_{i t}{ }^{*} D E R I V_{i t}+\gamma_{5} E B V_{i t}^{*} D E R I V_{i t} \\
& +\gamma_{6} D A C_{i t}+\tilde{a}_{7} E P S_{i t}{ }^{*} D A C_{i t}+ \\
& \gamma_{8} E B V_{i t}^{*} D A C_{i t}+\gamma_{9} S I Z E_{i t}+\gamma_{10} C S_{i t}+ \\
& \gamma_{11} G O_{i t}+\varepsilon_{i t}
\end{aligned}
$$

$$
\begin{aligned}
C A R_{i t}= & \beta_{0}+\beta_{1} \ddot{A E P S} S_{i t}+\beta_{2} \ddot{A E B V} V_{i t}+ \\
& \beta_{3} \Delta D E R I V_{i t}+ \\
& \beta_{4} \Delta E P S_{i t}^{*} \Delta D E R I V_{i t}+ \\
& \beta_{5} \ddot{A} E B V_{i t}^{*} \ddot{A} D E R I V_{i t} \\
& +\beta_{6} \Delta D A C_{i t}+\beta_{7} \Delta E P S_{i t}^{*} \Delta D A C_{i t} \\
& +\beta_{8} \Delta E B V_{i t}^{*} \Delta D A C_{i t}+\beta_{9} \Delta S I Z E_{i t} \\
& +\beta_{10} \Delta C S_{i t}+\beta_{11} \Delta G O_{i t}
\end{aligned}
$$

$$
\mathrm{CAR}_{\mathrm{it}}=\sum_{\mathrm{i}=1}^{\mathrm{n}} \mathrm{AR}_{\mathrm{it}}
$$

where, $\mathrm{AR}_{\mathrm{it}}$ is the level of abnormal returns of individual firm $i$ in month $t$, calculated using the equation: $A_{\mathrm{it}}=\mathrm{R}_{\mathrm{it}}-\mathrm{RM}_{\mathrm{t}}\left(\mathrm{R}_{\mathrm{it}}=\right.$ the level of individual actual returns of firm $i$ in month $t$, calculated by the closing price of firm $i$ in month $t:\left(\mathrm{P}_{\mathrm{it}}-\mathrm{P}_{\mathrm{it}}\right) / \mathrm{P}_{\mathrm{it}-1}$; and $\mathrm{RM}_{\mathrm{t}}(\mathrm{Mar}-$ ket return $)=$ the level of market returns in month $t$, calculated by the equation: ( $\mathrm{IHSG}_{\mathrm{t}}-$ IHSG $\left._{\mathrm{t}-1}\right) / \mathrm{IHSG}_{\mathrm{t}-1}$ is the $1 \mathrm{DX}$ Composite Index).

\section{Model for $\mathrm{H}_{4}$}

The difference between the effects of financial derivatives and discretionary accruals on the value relevance of earnings and equity.

The Wald test was used to test the difference between coefficient estimates. The null hypothesis suggests that there was no difference in coefficients. Two sets of variables were tested: (i) interaction variables between derivatives and earnings per share and interaction variables between discretionary accruals and earnings per share $\left(\gamma_{4}\right.$ and $\gamma_{7}$ ); and (ii) interaction variables between derivatives and equity book value and interaction variables between discretionary accruals and equity book value $\left(\gamma_{5}\right.$ and $\left.\gamma_{8}\right)$ :

$$
\begin{aligned}
\mathrm{P}_{\mathrm{it}}= & \gamma_{0}+\gamma_{1} \mathrm{EPS}_{\mathrm{it}}+\gamma_{2} \mathrm{EBV}_{\mathrm{it}}+\gamma_{3} \mathrm{DERIV}_{\mathrm{it}}+ \\
& \gamma_{4} \mathrm{EPS}_{\mathrm{it}} * \mathrm{DERIV}_{\mathrm{it}}+\gamma_{5} \mathrm{EBV}_{\mathrm{it}} * \mathrm{DERIV}_{\mathrm{it}} \\
& +\gamma_{6} \mathrm{DAC}_{\mathrm{it}}+\gamma_{7} \mathrm{EPS}_{\mathrm{it}} * \mathrm{DAC}_{\mathrm{it}}+ \\
& \gamma_{8} \mathrm{EBV}_{\mathrm{it}} \mathrm{DACC}_{\mathrm{it}}+\gamma_{9} \mathrm{SIZE}_{\mathrm{it}}+\gamma_{10} \mathrm{CS}_{\mathrm{it}}+ \\
& \gamma_{11} \mathrm{GO}_{\mathrm{it}}+\varepsilon_{\mathrm{it}}
\end{aligned}
$$




\section{Results and Discussion}

\section{Descriptive Statistics and Correlation Matrix}

The descriptive statistics in Table 1 show that financial derivatives are bigger than average discretionary accruals; this implies a frequent use of derivatives by firms. Standard deviation derivatives are slightly higher than discretionary accruals, which means that derivatives have dispersed variances. The
Dividend Payout Ratio has a minimum negative score since there were 91 observations that contained negative pre-managed earnings. Negative pre-managed earnings show that the firms' earnings have more discretionary accruals compared to cash flows (Sun and Rath 2010). Firm Size has a relatively high standard deviation, almost reaching the mean value, which indicates that the research sample contains various sizes of firms. Audit Quality indicates that 80 percent of firms using financial derivatives were audited by

Table 1. Descriptive Statistics

\begin{tabular}{lccccc}
\hline Variables & Mean & Median & Maximum & Minimum & Std. Dev. \\
\hline DERIV & 0.1710 & 0.1336 & 0.4278 & 0.0003 & 0.1387 \\
DAC & 0.1277 & 0.0852 & 0.4403 & 0.0057 & 0.1218 \\
CS & 0.5844 & 0.5986 & 0.9424 & 0.1881 & 0.1851 \\
GO & 2.0204 & 1.4994 & 6.1352 & 0.0736 & 1.8107 \\
IA & -0.0003 & -0.0118 & 0.0585 & -0.0257 & 0.0264 \\
DPR & 0.1310 & 0.0000 & 1.1152 & -0.4246 & 0.4143 \\
QA & 0.8265 & 1.0000 & 1.0000 & 0.0000 & 0.3796 \\
SIZE * & $7,638.36$ & $4,536.74$ & $26,573.55$ & 375.39 & $7,770.02$ \\
P** & $3,063.37$ & 930.00 & $13,100.00$ & 100.00 & $4,019.08$ \\
CAR & -0.0532 & -0.0515 & 0.7639 & -0.8148 & 0.4340 \\
EPS & 250.2709 & 70.0000 & $1,403.0000$ & -65.6799 & 412.7108 \\
EBV & $1,567.598$ & 770.470 & $6,089.700$ & 20.750 & $1,731.630$ \\
D.Spec & 0.7899 & 1.0000 & 1.0000 & 0.0000 & 0.4082 \\
\hline
\end{tabular}

Note:DERIV: derivatives; DAC: discretionary accruals; CS: capital structure; GO: growth opportunity; IA: information assymetry; DPR: dividend payout ratio without negative pre-managed earnings; QA: quality of audit; SIZE: firm's size; P: stock prices; CAR: cumulative abnormal return; EPS: earning per share; EBV: equity book value; D.spec: Dspeculation. $*$ in billions Rupiah. $* *_{\text {in }}$ Rupiah 
big-four public accounting firms. Standard deviations from stock prices in this research are higher than the average value, which indicates that stock price data in these variables have many variances. Dspeculation $(\mathrm{D}=1)$ shows speculative activities (nine observations) and hedging that was noncompliant with PSAK 55/1999 (150 observations) is larger than $\mathrm{D}=0$, which shows hedging activities (40 observations).
The correlation matrix, as shown in Table 2, reveals that derivatives (DERIV) and discretionary accruals (DAC) have a significant and positive correlation. This correlation suggests that the higher the derivatives the higher the discretionary accruals, or vice versa. In conclusion, a positive correlation between derivatives and discretionary accruals is complementary in nature.

Table 2. Correlation Matrix

\begin{tabular}{|c|c|c|c|c|c|c|c|c|c|}
\hline VARIABLES & DAC & DERIV & IA & DPR & $\begin{array}{l}\text { DPR_- } \\
\text { PLUS }\end{array}$ & QA & GO & CS & SIZE \\
\hline $\mathrm{DAC}$ & 1 & & & & & & & & \\
\hline $\begin{array}{l}\text { DERIV } \\
\text { p-value }\end{array}$ & $\begin{array}{l}0.16 \\
0.05^{*}\end{array}$ & 1 & & & & & & & \\
\hline $\begin{array}{l}\text { IA } \\
\text { p-value }\end{array}$ & $\begin{array}{l}0.21 \\
0.01 * * *\end{array}$ & $\begin{array}{l}0.01 \\
0.91\end{array}$ & 1 & & & & & & \\
\hline $\begin{array}{l}\text { DPR } \\
\text { p-value }\end{array}$ & $\begin{array}{l}-0.25 \\
0.00^{* * *}\end{array}$ & $\begin{array}{l}-0.1 \\
0.21\end{array}$ & $\begin{array}{l}-0.2 \\
0.01 * * *\end{array}$ & 1 & & & & & \\
\hline $\begin{array}{l}\text { DPR_PLUS } \\
\text { p-value }\end{array}$ & $\begin{array}{l}-0.25 \\
0.00^{* * *}\end{array}$ & $\begin{array}{l}-0.1 \\
0.21\end{array}$ & $\begin{array}{l}-0.2 \\
0.01 * * *\end{array}$ & $\mathrm{NA}$ & 1 & & & & \\
\hline $\begin{array}{l}\text { QA } \\
\text { p-value }\end{array}$ & $\begin{array}{l}0 \\
0.97\end{array}$ & $\begin{array}{l}-0.19 \\
0.02^{* *}\end{array}$ & $\begin{array}{l}-0.19 \\
0.2\end{array}$ & $\begin{array}{l}0.07 \\
0.37\end{array}$ & $\begin{array}{l}0.07 \\
0.37\end{array}$ & 1 & & & \\
\hline $\begin{array}{l}\mathrm{GO} \\
\mathrm{p} \text {-value }\end{array}$ & $\begin{array}{l}-0.15 \\
0.07^{*}\end{array}$ & $\begin{array}{l}-0.11 \\
0.18\end{array}$ & $\begin{array}{l}-0.38 \\
0.00 * * *\end{array}$ & $\begin{array}{l}0.5 \\
0.00 * * *\end{array}$ & $\begin{array}{l}0.5 \\
0.00^{* * *}\end{array}$ & $\begin{array}{l}0.02 \\
0.83\end{array}$ & 1 & & \\
\hline $\begin{array}{l}\mathrm{CS} \\
\mathrm{p} \text {-value }\end{array}$ & $\begin{array}{l}0.19 \\
0.02 * *\end{array}$ & $\begin{array}{l}0.21 \\
0.01 * * *\end{array}$ & $\begin{array}{l}0.15 \\
0.06^{* *}\end{array}$ & $\begin{array}{l}-0.19 \\
0.02 * * *\end{array}$ & $\begin{array}{l}-0.19 \\
0.02 * *\end{array}$ & $\begin{array}{l}0.13 \\
0.12\end{array}$ & $\begin{array}{l}-0.23 \\
0.00^{* * *}\end{array}$ & 1 & \\
\hline $\begin{array}{l}\text { SIZE } \\
\text { p-value }\end{array}$ & $\begin{array}{l}-0.21 \\
0.01^{* * *} \\
\end{array}$ & $\begin{array}{l}-0.05 \\
0.54 \\
\end{array}$ & $\begin{array}{l}-0.5 \\
0.00^{* * *} \\
\end{array}$ & $\begin{array}{l}0.12 \\
0.13 \\
\end{array}$ & $\begin{array}{l}0.12 \\
0.13 \\
\end{array}$ & $\begin{array}{l}0.13 \\
0.05 \\
\end{array}$ & $\begin{array}{l}0.19 \\
0.02 * * \\
\end{array}$ & $\begin{array}{l}-0.13 \\
0.02 * * \\
\end{array}$ & 1 \\
\hline
\end{tabular}

*** Significant at 1 percent; ** Significant at 5 percent *; Significant at 10 percent 


\section{The Results of Hypothesis 1}

Test results of the effects of financial derivatives on discretionary accruals using a dividend payout ratio with and without negative pre-managed earnings showed that financial derivatives were positively associated with discretionary accruals as predicted. The main objective of the classification test was to find out whether those engaged in hedging that were noncompliant with PSAK 55 (1999) tended to do so speculatively. Barton (2001) argued that derivatives had a negative or substitution relationship with discretionary accruals, which meant derivatives served as a hedging transaction. Meanwhile, derivatives that had a positive or complementary relationship with discretionary accruals served as speculative activities. Speculatives occured when both speculative and hedging actions that were noncompliant with PSAK 55(1999) had a positive relationship with discretionary accruals. The results were as follows: $\mathrm{D}=0$, if $\alpha_{1} \mathrm{DERIV}_{\text {it }}(0.6113)=$ positive significant; and $\mathrm{D}=1$, if $\alpha_{1} \mathrm{DERIV}_{\text {it }}$ $(0.6113)+\alpha_{8}$ DERIV $^{*}$ speculation $(-0.5394)$ $=$ positive significant. This shows that there is a positive or complementary relationship between financial derivatives (speculative and hedging that was noncompliant with PSAK 55, 1999) and discretionary accruals. This test therefore supports $\mathrm{H}_{1}$.

Table 3. The Effects of Financial Derivatives on Discretionary Accruals using a Dividend Payout Ration measured with and without Negative Pre-managed Earnings

$\mathrm{DAC}_{\mathrm{it}}=\alpha_{0}+\alpha_{1} \mathrm{DERIV}_{\mathrm{it}}+\alpha_{2} \mathrm{CSit}+\alpha_{3} \mathrm{GO}_{\mathrm{it}}+\alpha_{4} \mathrm{IA}_{\mathrm{it}}+\alpha_{5} \mathrm{DAC}_{\mathrm{t}-1}+\alpha_{6} \mathrm{DPR}_{\mathrm{it}}+\alpha_{8} \mathrm{QA}_{\mathrm{it}}+\alpha_{8} \mathrm{DERIV}^{*}$ Speculation $+\alpha$ ${ }_{9}$ DSpeculation $+\varepsilon_{\mathrm{i}}$

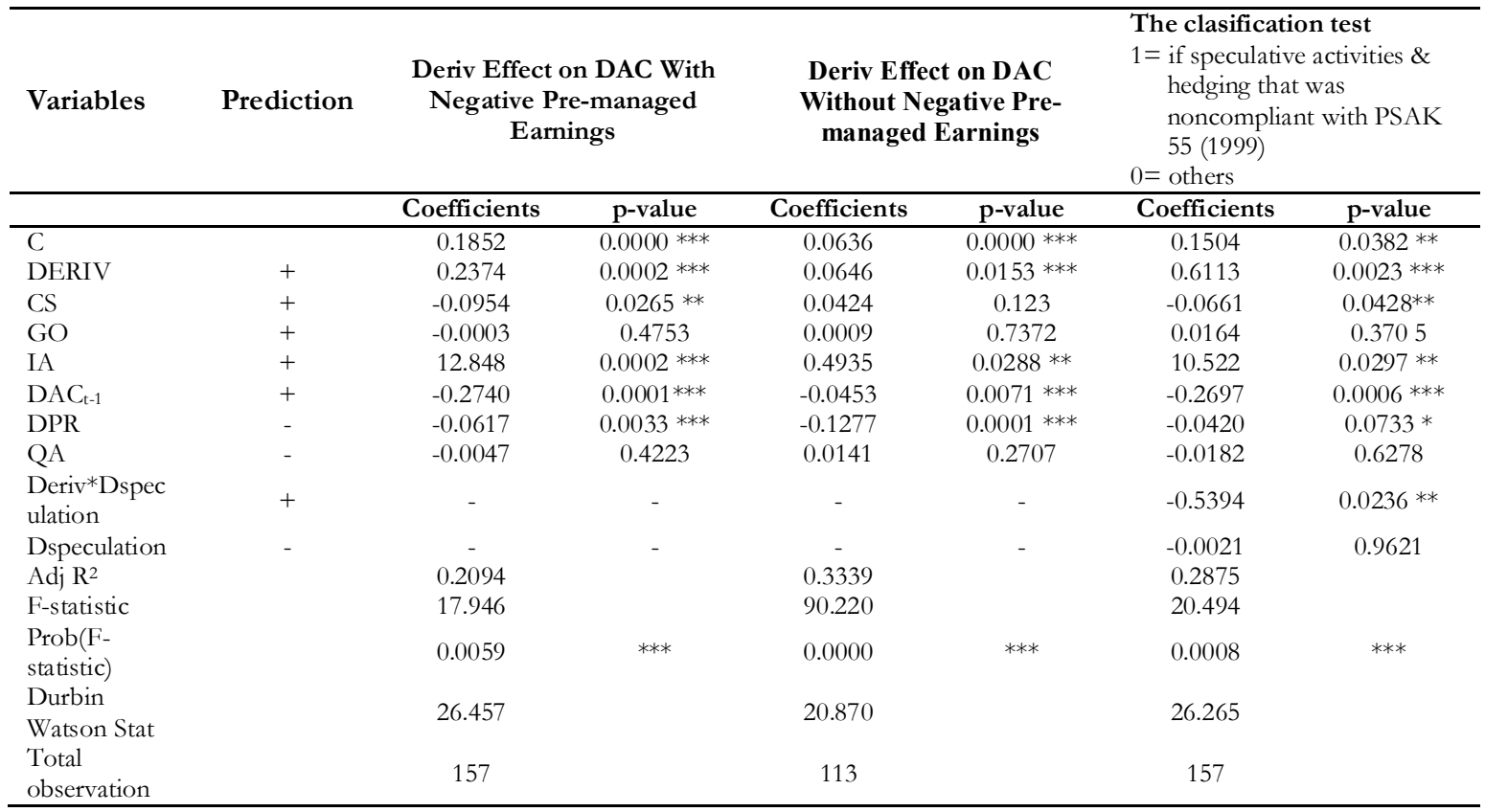

$* * *$ Significant at a level of 1 percent; **Significant at a level of 5 percent; $*$ Significant at a level of 10 percent

Note: $\mathrm{DAC}_{\mathrm{it}}$ : Absolute discretionary accruals firm $i$ in year $t$, DERIV $_{\mathrm{it}}$ : derivatives of firm $i$ in year $t$; CS $_{\mathrm{it}}$ : leverage of firm $i$ in year $t$; $\mathrm{GO}_{\mathrm{it}}$ : growth opportunity of firm $i$ in year $t$ IA $_{\mathrm{it}}$ : information asymmetry of firm $i$ in year $t$, DAC ${ }_{\mathrm{it}-1}$ : absolute discretionary accrual firm $\mathrm{i}$ in the prior-year period; $\mathrm{DPR}_{\mathrm{it}}$ : dividend payout ratio of firm $i$ in year $t, \mathrm{QA}_{\mathrm{it}}$ : dummy of the quality of audit. 1 if a firm uses big-four auditors and 0 if not, Dspeculation=dummy of speculation, Deriv*Dspeculation: Interaction between derivatives and DSpeculation. 
The test on the control variables showed that capital structure had a negative and significant association. This suggested that a higher level of debt leads to lower discretionary accruals (Jelinek 2007). This is consistent with the agency theory (Jensen dan Meckling 1976) that stated that the larger debt ratio was, the larger the risk of debt covenant violation. Therefore, creditors mitigate the risk of debt covenant violation by monitoring more closely managerial discretion for the reduction of discretionary accruals. Meanwhile, prior-year discretionary accruals had negative and significant results. This suggested volatile earnings, which may result from speculative activities. The growth variable showed significant results, which may be explained by the already mature firms in the sample whose growth opportunities are no longer the dominant factor that affects their discretionary accruals, or they show high growth through means other than discretionary accruals. Quality of Audit yielded insignificant results, which suggested that hiring big-four auditors did not necessarily cut down on the aggressive use of accrual earnings.

\section{The Results of Hypotheses 2 and 3}

The test for the effects of financial derivatives on the value relevance of earnings (EPS*DERIV) using the stock price, cumulative abnormal return, and deflated by shares outstanding as dependent variables models showed negative and significant results as predicted, while the effects of derivatives on the value relevance of equity (EBV*DERIV) showed insignificant results. Moreover, the tests on the effects of discretionary accruals on the value relevance of earnings (EPS*DAC) using cumulative abnormal returns and the deflated by outstanding shares model both showed as being negative and sig- nificant. However, when using the price model, the effect is insignificant. The effects of discretionary accruals on the value relevance of equity book value $\left(\mathrm{EBV}^{*} \mathrm{DAC}\right)$ were significant and negative only in the price model which suggested that discretionary accruals weaken the value relevance of equity.

The earnings per share showed positive and significant results, which were consistent across the three models. This suggests that the market believes that earnings per share is capable of providing information about firms' operations. The book value of equity was positively and significantly associated as predicted. These findings showed that the market pays heed to earnings and book value of equity (Kothari and Zimmerman 1995; Feltham and Ohlson 1995). The book value of equity with cumulative abnormal return model showed insignificant results.

The test on the effects of derivatives on the three models showed insignificant results, driven by the fact that derivatives information associated with unrealized gains/ losses is a relatively new variable in financial reporting, which renders it less relevant in accounting for dependent variables (Kothari and Zimmerman 1995). Therefore, derivatives are yet to be used to help make decisions in the capital markets, as it is earnings, not derivatives, that count for most investors. Furthermore, the test on discretionary accruals using cumulative abnormal returns and deflated by shares outstanding models yielded insignificant results. The findings showed that the market may find it difficult to detect whether earnings management by firms was efficient or opportunistic in nature, so the markets opt not to respond. This study supports Feltham and Pae (2000). Using the price model, however, the effect was significantly positive. 
Table 4. The effects of Financial Derivatives and Discretionary Accruals on The Value Relevance of Earnings and Equity with Price (P), Cumulative Abnormal Return (CAR), and deflated by outstanding shares model

\begin{tabular}{|c|c|c|c|c|c|c|}
\hline \multirow[t]{2}{*}{ Variables } & \multicolumn{2}{|c|}{ Stock Price (P) Model } & \multicolumn{2}{|c|}{$\begin{array}{l}\text { Cumulative Abnormal } \\
\text { Return (CAR) Model }\end{array}$} & \multicolumn{2}{|c|}{$\begin{array}{c}\text { Deflated by } \\
\text { Outstanding Shares Model }\end{array}$} \\
\hline & Coefficients & p-value & Coefficients & p-value & Coefficients & p-value \\
\hline $\mathrm{C}$ & 74.223 & $0.0004 * * *$ & 0.0039 & 0.9465 & 1.112 .621 & 0.4504 \\
\hline EPS & 0.0003 & $0.0070 * * *$ & 0.0151 & $0.0414 * *$ & 1.807 .265 & $0.0086 * * *$ \\
\hline EBV & 0.0004 & $0.0000 * * *$ & -0.0176 & 0.1230 & 1.625 .612 & $0.0000 * * *$ \\
\hline DERIV & -0.3469 & 0.5426 & 0.0066 & 0.3084 & -0.056402 & 0.8202 \\
\hline $\begin{array}{l}\text { EPS*DERI } \\
\mathrm{V}\end{array}$ & -0.0015 & $0.0380 * *$ & -0.0026 & $0.0758 *$ & -0.001312 & $0.0039 * * *$ \\
\hline $\begin{array}{l}\text { EBV*DERI } \\
\text { V }\end{array}$ & 0.0002 & 0.1550 & -0.0161 & 0.5764 & $-8.32 \mathrm{E}-05$ & 0.5138 \\
\hline DAC & 0.5895 & $0.0395 * *$ & 0.0058 & 0.3069 & -0.705800 & 0.1043 \\
\hline EPS*DAC & -0.0017 & 0.3921 & -0.0054 & $0.0985 *$ & -0.000156 & $0.0082^{* * *}$ \\
\hline $\mathrm{EBV} * \mathrm{DAC}$ & -0.0004 & $0.0001 * * *$ & -0.0168 & 0.2229 & 0.000102 & 0.6384 \\
\hline SIZE & -0.0471 & 0.5096 & -25.221 & 0.3819 & -4.037 .356 & 0.8592 \\
\hline CS & -0.2181 & 0.2500 & 0.0064 & 0.9322 & -7.937 .411 & 0.2607 \\
\hline GO & 0.3047 & $0.0000 * * *$ & -0.0894 & $0.0001 * * *$ & 8.758 .729 & $0.0000 * * *$ \\
\hline Adjusted $\mathrm{R}^{2}$ & 0.8852 & & 0.0693 & & 0.8677 & \\
\hline F-statistic & 258.522 & & 19.883 & & 221.342 & \\
\hline Prob (F-statistic) & 0.0000 & $* * *$ & 0.0340 & $* * *$ & 0.0000 & $* * *$ \\
\hline Durbin-Watson stat & 19.235 & & 20.080 & & 23.765 & \\
\hline
\end{tabular}

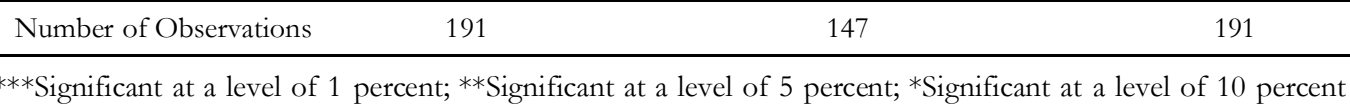

Note: CAR $_{\mathrm{it}}$ : Cumulative Abnormal Return of firm $i$ in year $t$, EPS: Earning per Share; EBV: Equity Book Value; DERIV: Derivatives; EPS*DERIV: An interaction between EPS and DERIV; EPS*DAC: An interaction between EPS and discretionary accruals; DAC: Discretionary accruals; EPS*DAC : An interaction between EPS and DAC; EBV*DAC: An interaction between EBV and DAC; SIZE: Firm Size; CS: Capital Structure, GO: Growth Opportunity

Ultimately, the test of control variables on firm size showed insignificant results due to the easier availability of non-accounting information that enables the markets to interpret financial reports more accurately and reduces markets responses to firms' earnings announcements. The Capital Structure vari- able showed insignificant results due to the fact that firms prioritize creditors over shareholders when they face financial distress. This explains why firms' share prices are not affected by their large debts (Dhaliwal et al. 1991). 


\section{Test Results of Hypothesis 4}

The test on $\mathrm{H}_{4.1}$ (Table 5) about the difference between the effects of derivatives and discretionary accruals on the value relevance of earnings showed that both price and return models yielded insignificant results, meaning there were no differences between the effects of derivatives and discretionary accruals on the value relevance of earnings. The test result of $\mathrm{H}_{4.2}$ using the price model implied that EBV*DERIV -
$\mathrm{EBV}^{*} \mathrm{DAC}>0$, meaning the coefficient of EBV*DERIV was significantly larger (different) than the coefficient of $\mathrm{EBV}^{*} \mathrm{DAC}$. This implied that there was a difference between the effects of financial derivatives and discretionary accruals on the value relevance of equity book value. Financial derivatives had a positive effect and a significantly larger (different) effect on the value relevance of equity book value compared to discretionary accruals.

Table 5. Wald Test on the Difference between the Coefficient of Financial Derivatives and Discretionary Accruals and the Relationship between Earnings and Equity Book Value

$$
\begin{aligned}
& P_{\mathrm{it}}=\gamma_{0}+\gamma_{1} \mathrm{EPS}_{\mathrm{it}}+\gamma_{2} \mathrm{EBV}_{\mathrm{it}}+\gamma_{3} \mathrm{DERIV}_{\mathrm{it}}+\gamma_{4} \mathrm{EPS}_{\mathrm{it}} * \mathrm{DERIV}_{\mathrm{it}}+\gamma_{5} \mathrm{EBV}_{\mathrm{it}} * \mathrm{DERIV}_{\mathrm{it}}+\gamma_{6} \mathrm{DAC}_{\mathrm{it}}+\gamma_{7} \mathrm{EPS}_{\mathrm{it}}{ }^{*} \mathrm{DAC}_{\mathrm{it}}+ \\
& \gamma_{8} \mathrm{EBV}_{\mathrm{it}}^{*} \mathrm{DAC}_{\mathrm{it}}+\gamma_{9} \mathrm{SIZE}_{\mathrm{it}}+\gamma_{10} \mathrm{CS}_{\mathrm{it}}+\gamma_{11} \mathrm{GO}_{\mathrm{it}}+\mathrm{e}_{\mathrm{it}} \\
& \mathrm{CAR}=\beta_{0}+\beta_{1} \Delta \mathrm{EPS}_{\mathrm{it}}+\beta_{2} \Delta \mathrm{EBV}_{\mathrm{it}}+\beta_{3} \Delta \text { DERIV }_{\mathrm{it}}+\beta_{4} \Delta \mathrm{EPS}_{\mathrm{it}}^{*} \Delta \mathrm{DERIV}_{\mathrm{it}}+\beta_{5} \Delta \mathrm{EBV}_{\mathrm{it}} * \Delta \mathrm{DERIV}_{\mathrm{it}}+\beta_{6} \Delta \mathrm{DAC}_{\mathrm{it}}+ \\
& \beta_{7} \Delta \mathrm{EPS}_{\mathrm{it}}^{*} \Delta \mathrm{DAC}_{\mathrm{it}}+\beta_{8} \Delta \mathrm{EBV}_{\mathrm{it}}^{*} \Delta \mathrm{DAC}_{\mathrm{it}}+\beta_{9} \Delta \mathrm{SIZE}_{\mathrm{it}}+\beta_{10} \Delta \mathrm{CS}_{\mathrm{it}}+\beta_{11} \Delta \mathrm{GO}_{\mathrm{it}}
\end{aligned}
$$

\begin{tabular}{lcc}
\hline Wald Test: & Price Model & CAR Model \\
H0: EPS*DERIV - EPS*DAC $=0$ & 0.9541 & \\
\hline F-Test: $\gamma_{4}=\gamma_{7}$ & & 0.4169 \\
$\beta_{4}=\beta_{7}$ & & \\
H0: EBV*DERIV - EBV*DAC $=0$ & $0.0000 * * *$ & \\
F-Test: $\gamma_{5}=\gamma_{8}$ & & 0.9822 \\
$\beta_{5}=\beta_{8}$ & & \\
\hline
\end{tabular}

\footnotetext{
***Significant at a level of 1 percent; **Significant at a level of 5 percent; *Significant at a level of 10 percent

$\mathrm{H}_{0}$ : Coeff. EPS*DERIV - Coeff. EPS*DAC $=0 ; \mathrm{H}_{1}$ : Coeff. EPS*DERIV - Coeff. EPS*DAC “ 0

$\mathrm{H}_{0}$ : Coeff. EBV*DERIV - Coeff. EBV*DAC $=0 ; \mathrm{H}_{1}$ : Coeff. EBV*DERIV - Coeff. EBV*DAC “ 0
} 


\section{Discussion}

The correlation matrix test result showed that financial derivatives and discretionary accruals had a significant and positive correlation, which meant that they were complementary. Meanwhile, the test on $\mathrm{H}_{1}$ showed that a dividend payout ratio with and without negative pre-managed earnings yielded the same results. The effects of financial derivatives on discretionary accruals consistently showed a positive and significant association. The result infers that firms directly recognized unrealized gains/losses of derivatives in their income statements, as if they were speculative activities. However, speculative activities increase earnings volatility, prompting managers to increase discretionary accruals to stabilize earnings. These findings are consistent with Barton (2001) who suggested that the existence of a positive or complementary association between derivatives and discretionary accruals indicated that a higher use of speculative activities intensifies the use of discretionary accruals.

The classification test on financial derivatives showed that nine financial derivatives were reported as speculative and 150 financial derivatives were reported as hedging that were noncompliant with PSAK 55 (1999). It implied that most $(79.9 \%)$ financial derivatives users were conducting speculative actions. Hence, the test result supports $\mathrm{H}_{1}$, namely there is a positive or complementary relationship between financial derivatives and discretionary accruals. This result is in line with Wild et al. (2004), who argued that many firms speculate (implicitly), although they disclose their derivatives as hedging.

The result of $\mathrm{H}_{2}$ implied that the effects of financial derivatives on the values rel- evance or earnings (EPS*DERIV) of the three models were significant and negative. This suggests that financial derivatives weaken the relationship between accounting earnings proxied with earnings per share and stock prices. When associated with the test results of $\mathrm{H}_{1}$ which showed that speculative activities were at play in a complementary relationship, the unrealized gains/losses were, thus, directly recognized in the current year's income statement. As Aabo (2007) noted, this leads to an earnings volatility that is higher than hedging. Consequently, this higher earnings volatility decreases market responses to stock prices (Graham et al. 2005). Financial derivatives, hence, are negatively associated with the value relevance of earnings, which suggests that speculative activities lead to a weaker relationship between prices and earnings. The effects of derivatives on the value relevance of equity (EBV*DERIV) showed insignificant results, which were anomalous as the use of derivatives that were compliant with PSAK 55 (1999) should increase the value relevance of book value while the use of derivatives that were noncompliant with PSAK 55 (1999) should decrease the value relevance of book value.

The findings showed that discretionary accruals within the stock price model had no effect on the value relevance of earnings (EPS*DAC), which is consistent with Whelan and McNamara (2004). This may stem from less accurate accounting practices that generated earnings of questionable quality or lower earnings reliability. Discretionary accruals, hence, have no effects that strengthen or weaken the relationship between prices and earnings. On the contrary, the effects of discretionary accruals on value relevance of earnings using both cumulative abnormal return and deflated by the number of outstanding shares model, were significantly negative. 
This may stem from opportunistic discretionary accruals decreasing earnings reliability. This shows that discretionary accruals can potentially decrease the value relevance of earnings.

Interestingly, the test on the effects of discretionary accruals on the value relevance of equity (EBV*DAC) using cumulative abnormal return and deflated by outstanding shares models showed insignificant results. This was consistent with Feltham and Ohlson (1995) models' which proposed that earnings were part of the components of book value of equity in the balance sheet. This suggests that the more accurate the book value of equity the more unbiased the value relevance of equity. However, low earnings reliability due to opportunistic discretionary accruals could give rise to errors in normal earnings estimates, resulting in discretionary accruals having no effects on the value relevance of equity. However, when using the price model, the effect is significantly negative, which suggests that discretionary accruals weaken the value relevance of equity.

Moreover, the test on the differences between the effects of financial derivatives and discretionary accruals on the value relevance of earnings using both price and return models showed statistically insignificant results. The test on the differences between the effects of financial derivatives and discretionary accruals on the value relevance of equity using the price model showed a positively significant result. This implied that derivatives had a positively significant and larger (different) association with the value relevance of equity book value compared to discretionary accruals. Meanwhile, the test using the return model found no significant associations.

\section{Conclusions}

The relationship between financial derivatives and discretionary accruals was positively significant. The findings showed that a higher use of speculative activities would be followed by a higher use of discretionary accruals in a complementary manner, consistent with the prediction of Barton (2001). Based on the observations in the notes for financial statements, firms were not yet ready to comply with the tight requirements of hedging disclosure in PSAK 55 (1999). Hence, managers resorted to using accounting treatments for speculative actions to recognize unrealized gains/losses from derivatives in the current year's income statements. This gave rise to earnings volatility that was higher than hedging (Aabo 2007), prompting managers to conduct earnings management.

The relationship between financial derivatives was negatively associated with the value relevance of earnings using the three models. This finding was developed from the first hypothesis in which a complementary relationship in speculative activities weakens the associations between accounting earnings and stock prices (Graham et al. 2005), which eventually weakens the value relevance of earnings. Meanwhile, the test on the effects of discretionary accruals on the value relevance of earnings yielded mixed results; it was significantly negative using a return and deflated by outstanding shares model but statistically insignificant using a price model, consistent with Whelan and McNamara (2004) and Wiedman and Marquardt (2004). However, derivatives and discretionary accruals do not have effects on the value relevance of equity, except for discretionary accruals which have a significant and posi- 
tive effect on the value relevance of equity with a price model.

According to Nissim and Penman (2003), there was a change in the instruments used to detect earnings management from accruals activity to real financial activities following the imposition of the SarbanesOxley Act (Cohen et al. 2004). This is consistent with what this study found, namely real activities such as financial derivatives are value-relevant, while discretionary accruals are not. Therefore, it is advisable that investors exercise caution against a shift in earnings management activities.
Based on the sample data from financial statements, firms used financial derivatives that were comprised of, based on types of contract, cross-currency swaps $(48 \%)$, interest rate swaps $(25 \%)$, cross-currency interest rate swaps $(9 \%)$, forwards $(10 \%)$ and options $(8 \%)$. However, this study did not test samples based on those types of financial derivatives because of a lack of sufficient data. Separating the data further would minimize the data proportion that may result in inadequate test results. This being the case, it is recommended that future research groups such transactions into swaps, forwards and options.

\section{References}

Aabo, T. 2007. The Impact of individual-owners on currency speculation: The case of danish nonfinancial firms. International Journal of Managerial Finance 3 (1): 92-107.

Ali, Z. P. 1992. The role of earnings levels in annual earnings-returns studies. Journal of Accounting Research 30 (2): 286-296.

Asquith, P., A. Beatty, and J. Weber. 2005. Performance pricing in bank debt contracts. Accounting Review 40: $101-128$.

Barth, M. E., W. H. Beaver, and W. R. Landsman. 1998. Relative valuation roles of equity book value and net income as a function of financial health. Journal of Accounting and Economics 25 (1): 1-34.

Barton, J. 2001. Does the use of financial derivatives affect earnings management decisions? The Accounting Review 76 (1): 1-26.

Beaver. W. H. 1998. Financial Reporting: An Accounting Revolution (3 ${ }^{\text {rd }}$ ed.). Upper Saddle River, NJ: PrenticeHall

Brown, S. J., and J. B. Warner. 1985. Measuring security price performance. Journal of Financial Economics 8: 205-258.

Burgstahler, D., and I. Dichev. 1997. Earnings management to avoid earnings decreases and losses. Journal of Accounting and Economics 24: 99-126.

Collins, D. W., and S. P. Kothari. 1989. An analysis of intertemporal and cross-sectional determinants of earnings response coefficients. Journal of Accounting Research 11: 143-82.

Cohen, D. A., A. Dey, and T. Z. Lys. 2004. Trends in earnings management and informativeness of earnings announcements in the pre- and post-Sarbanes-Oxley periods. Northwestern University workingpaper.

Djohanputro, B. 2008. Manajemen Risiko Korporat. Jakarta, Indonesia: PPM Manajemen. 
Easton, P. D., P. H. Eddey, and T. S. Harris. 1998. An investigation of revaluations of tangible long-lived assets. Journal of Accounting Research 31 (supp): 1-38.

Feltham, G. A., and J. A. Ohlson. 1995. Valuation and clean surplus accounting for operating and financial activities. Contemporary Accounting Research (Spring).

Feltham, G. A., and J. Pae. 2000. Analysis of the impact of accounting accruals on earnings uncertainty and response coefficient. Journal of Accounting Auditing and Finance 15 (3): 199-236.

Financial Accounting Standard Board (FASB) 1998. Accounting for derivative instruments and hedging activities. Statement of Financial Accounting Standard (SFAS) No. 133.

Graham, J. R., H. R. Campbell, and S. Rajgopal. 2005. The economic implications of corporate financial reporting, Journal of Accounting and Economics 40.

Greene, W. H. 2003. Econometric Analysis ( $5^{\text {th }}$ ed.). New Jersey: Prentice-Hall.

Gujarati, D. N. 2003. Basic Econometrics ( $3^{\text {rd }}$ ed.). McGraw-Hill Book Co.

Huang, P., T. J. Louwers, J. S. Moffitt, and Y. Zhang. 2008. Ethical management, corporate governance, and abnormal accruals. Journal of Business Ethics 83 (3): 469-487.

Ikatan Akuntan Indonesia. 1999. Pernyataan Standar Akuntansi Keuangan (PSAK) No.55, Instrumen Keuangan: Pengakuan dan Pengukuran. Jakarta: Salemba Empat.

Ikatan Akuntan Indonesia. 2006. Pernyataan Standar Akuntansi Keuangan (PSAK) No.55, Instrumen Keuangan :Pengakuan dan Pengukuran. Jakarta: Salemba Empat.

Jelinek, K. 2007. The effect of leverage increases on earnings management. Journal of Business and Economic Studies 13: 24-46.

Kothari, S. P., A. J. Leone, and C. E. Wasley. 2005. Performance matched discretionary accrual measures. Journal of Accounting and Economics 39: 163-197.

Kothari, S. P. and J. L. Zimmerman. 1995. Price and return models. Journal of Accounting and Economics 20 (2): 155-192.

Indonesian Bank Accounting Guideline (PAPI). 2008. Jakarta, Indonesia: Bank Indonesia.

Lee, C. M. C. 1993. Market fragmentation and price execution in NYSE-listed securities. Journal of Finance 48: 1009-1038.

Lev, B., and P. Zarowin. 1999. The boundaries of financial reporting and how to extend them. Joumal of Research Accounting 37 (2): 353-383.

Moffitt, J. S. 2001. The effect of derivative use on discretionary accruals. PhD Dissertation. Dept. of Accounting, Florida State University.

Nissim, D., and H. Penman. 2003. The association between changes in interest rates, earnings and equity values. Contemporary Accounting Research 20 (4): 775-804.

Pincus, M. and S. Rajgopal. 2002. The interaction between accrual management and hedging: Evidence from oil and gas firms. The Accounting Review 77 (1): 127-160.

Richardson, S. A., R. G. Sloan, M. T. Soliman, and I. Tuna. 2004. Accrual reliability, earnings persistence and stock prices. Working Paper. The Wharton School, University of Pennsylvania.

Sloan, R. D. 1996. Do stock prices fully reflect information in accruals about future earnings? The Accounting Review 71 (3): 289-315. 
Subramanyam, K. R.1996. The pricing of discretionary accruals. Journal of Accounting and Economics 22 (Aug-Dec): 249-281.

Sun, L., and S. Rath. 2010. Ex-ante pre managed earnings benchmarks and earnings management of Australian firms. wnm.ssrn.com.

Watts, R. L., and J. L. Zimmerman. 1986. Positive Accounting Theory. Eaglewood Cliffs, New Jersey, USA: Prentice Hall Inc.

Whelan, C., and R. McNamara. 2004. The impact of earnings management on the value-relevance of financial statement information. Social Science Research Network (SSRN) (July). wnm.ssrn.com.

Wiedman, C. I., and C. A. Marquardt. 2004. The effect of earnings management on the value relevance of accounting information. Journal of Business Finance and Accounting 31 (3): 297-332

Wild, J. J., K. R.Subramanyam, and R. F. Halsey. 2004. Financial Statement Analysis (8 $8^{\text {th }}$ ed.). McGraw Hill.

Zhang, G. 2000. Accounting information, capital investment decision and equity valuation: Theory and empirical. Journal of Accounting Research 38 (2): 271-295. 